\title{
MURABAHAH \\ (Prinsip dan Mekanismenya Dalam Perbankan Islam)
}

\author{
Ismail Hannanong \\ Sekolah Tinggi Agama Islam Al-Gazali Barru \\ Email: ismailhannanong74@yahoo.com
}

\begin{abstract}
This paper will discuss the mechanism of murabahah agreement and application in Islamic banking, and compare murabahah finance with fixed interest to banks in several key areas. Islamic banks have used murabahah agreements in financing activities through merchandise and expanded their network of uses. Murabahah finance and higher credit prices therein clearly indicate that there is a time value in financing based on murabahah, which leads though not directly to the acceptance of the time value of money.
\end{abstract}

\begin{abstract}
Abstrak: Tulisan ini akan membahas mekanisme perjanjian murabahah dan penerapan dalam perbankan Islam, dan membandingkan keuangan murabahah dengan bunga tetap pada perbankan dalam beberapa bidang utama. Bank-bank Islam telah menggunakan perjanjian murabahah dalam aktivitas pembiayaan melalui barang-barang dagangan dan memperluas jaringan penggunaanya. Keuangan murabahah dan harga kredit yang lebih tinggi didalamnya jelas menunjukkan bahwa ada nilai waktu dalam pembiayaan yang berdasarkan murabahah, yang menuju walaupun tidak langsung kepada penerimaan nilai waktu uang.
\end{abstract}

Kata Kunci: Muamalah, Murabahah, dan Bank Syariah

\section{PENDAHULUAN}

Aspek Muamalah adalah juga merupakan komponen dasar dan bagian dari ajaran Islam universal, keterkaitan antara komponen ibadah, muamalah dan etika moral sangatlah urgen ketika ingin mengamalkan Islam secara kaffah, memisahkan salah satu dari ketiga komponen dalam praktek kehidupan sehari-hari, itu berarti pengamalan akan ajaran Islam belumlah optimal sebagaimana yang dikehendaki oleh prinsip dasar Al-Quran dan Sunnah Nabi. Dalam kehidupan sekarang, manusia tidak pernah terlepas dari interaksi satu sama lain, entah itu dalam aspek saling tolong menolong, atau take and give. Tapi dalam konsepsi Islam hendaknya hubungan take and give bukan atas dasar hanya mencari keuntungan demi untuk kepentingan pribadi, tapi semestinya aspek take and give tersebut tidak melupakan nilai tolonh menolong dan kerjasama yang saling menguntungkan sebagai bagian dari etika interaksi kemanusiaan. Salah satunya adalah dalam bentuk jual beli 
murabahah dan system bagi hasil dalam perbankan Islam.

Para pakar teori perbankan Islam mengemukakan bahwa perbankan Islam lebih berasarkan bagi hasil atau pembagian untung rugi, tidak berdasarkan bunga. Namun demikian, bank-bank Islam dalam prakteknya, sejak awal meyakini bahwa perbankan yang berdasarkan prinsip bagi hasil atau PLS ( Profit and Lost Sharing ) sulit untuk dilaksanakan karena sifatnya sangat riskan dan tidak pasti.

Masalah praktis yang menyertai pembiayaan ini menjadikan penurunan secara bertahap dalam perbankan Islam, dan menyebabkan peningkatan yang tetap dalam penerapan mekanisme pembiayaan seperti "bunga". Satu mekanisme itu diistilahkan dengan murabahah. Maka dalam makalah ini akan dibahas secara lengkap tentang Murabahah, mekanisme investasi paling penting dalam perbankan Islam saat ini. Mekanisme itu menunjukkan sifat dari perjanjian murabahah dan penerapan dalam perbankan Islam, dan membandingkan keuangan murabahah dengan bunga tetap pada perbankan dalam beberapa bidang utama. diketahui, sedangkan pengertian terminologisnya adalah : " Pembelian barang menurut rincian yang ditetapkan oleh pengutang, dengan keuntungan dan waktu pembayaran yang telah disepakati “2.

Ibnu Rusyd mendefenisikan sebagai berikut : jual beli barang pada harga asal dengan tambahan keuntungan yang disepakati. $^{3}$

Menuurut versi Bank Muamalat Indonesia melalui produk pembiayaan murabahahnya, yaitu : “ Akad jual beli antara nasabah dan bank. Bank membiayai ( membelikan ) kebutuhan investasi nasabah yang dijual dengan harga pokok ditambah dengan keuntungan yang diketahui dan disepakati bersama. Pembayaran dilakukan dengan cara mengansur selama jangka waktu yang telah ditentukan." Dalan buku " Menggagas Konsep Ekonomi Syariah " karya Husain dan Susanto disitu juga disebutkan tentang murabahah, yaitu : "jual beli barang pada harga asal dengan tambahan keuntungan yang disepakati antara pembeli pertama dan pembeli kedua. Pembeli pertama membeli barang dan kemudian ingin menjualnya kembali kepada calon pembeli yang lain untk memperoleh kentungan".

2. Murabahah Dalam Wacana Fiqih Pengertian murabahah dalam wacana fiqih, yaitu : ada tiga pihak, A, $\mathrm{B}$, dan $\mathrm{C}$ dalam membeli beberapa barang untuk A, B tidak memiliki barang tersebut tetapi berjanji untuk

\section{PEMBAHASAN}

\section{A. Pengertian Murabahah}

1. Pengertian jual beli murabahah secara etimologi : ${ }^{1}$

Jual beli yang terdapat di dalamnya ada tambahan keuntungan yang 
membelikannya dari pihak ketiga $\mathrm{C}, \mathrm{B}$ adalah seorang perantara, dan perjanjian murabahah antara A dan B. Perjanjian murabahah ini diartikan sebagai penjualan komoditas dalam harga yang pada mulanya penjual B membayarnya, ditambah sisa untung yang dikenakan kepada penjual $\mathrm{B}$ dan pembeli $\mathrm{A}^{4}$ Contoh lain yang ditulis oleh Dr. Muhammad Syafi'i Antonio ${ }^{5}$, misalnya : pedagang eceran membeli computer dari grosir dengan harga Rp. 10.000.000, kemudian menambahkan keuntungan sebesar Rp. 750.000 dn ia menjual kepada si pembeli dengan harga $\mathrm{Rp}$. 10.750.000. Pada umumnya, si pedagang eceran tidak akan memesan dari grosir sebelum ada pesanan dari calon pembeli dan mereka sudah menyepakati tentanng lama pembiayaan, besar keuntungan yang akan diambil pedagang eceran, serta besarnya angsuran kalau memang akan dibayar secara angsuran. Karena awalnya dalam hukum Islam, perjanjian murabahah Nampak telah diterapkan untuk tujuan perdagangan.

Udovitch menunjukkan bahwa murabahah adalah bentuk penjualan komisi, dimana pembeli yang biasanya tidak mampu memperoleh komoditas tersebut memerlukan pengecualian melalui seorang perantara, atau tidak ingin mengalami kesulitan, karenanya ia mencari jasa perantara tersebut. ${ }^{6}$

Namun Al-Quran tidak membuat acuan langsung berkenaan dengan murabahah, walaupun ada beberapa acuan didalamnya untuk menjual, keuntungan, kerugian, dan perdagangan.
Demikian juga, nampaknya tidak ada hadis yang memiliki acuan langsung kepada murabahah. Para ulama awal seperti Malik dan Syafi'i yang secara khusus menyatakan bahwa penjualan murabahah berlaku, tidak menyebutkan referensi dari hadis yang jelas.

Al-Kaff kritikus kontemporer menyimpulkan : "bahwa murabahah merupakan salah satu penjualan yang tidak dikenal sepanjang masa Nabi atau sahabatnya. "7 Menurutnya ulama yang masyhur mulai mengungkapkan pandangan mereka mengenai murabahah pada perempat pertama abad kedua hijrah atau lebih. Karena nampaknya tidak ada acuan langsung kepadanya dalam Al-Quran dan Al-hadis yang diterima secara umum, para ahli hukum harus membenarkan murabahah berdasarkan landasan yang lain. Malik mendukung validitasnya dengan acuan pada praktek orang-orang Madinah: "Ada consensus pendapat disini (di Madinah) mengenai hukum orang yang membeli baju disebuah kota, dan mengambilnya di kota lain untuk menjualnya berdasarkan suatu kesepakatan keuntungan. “8

Syafi'i tanpa bermaksud untuk membela pandangannya oleh teks syariah, mengatakan : Jika seseorang menunjukkan komoditas kepada seseorang dan mengatakan, kamu beli untukku, aku akan memberimu keuntungan begini, begini,"

Kemudian orang itu membelinya, maka transaksi itu sah “9 


\section{B. Murabahah dalam Sistem Perbankan Islam}

Bank-bank Islam mengambil murabahah untuk memberikan pembiayaan jangka pendek kepada kliennya untuk membeli barang walaupun klien tersebut mungkin tidak memiliki uang tunai untuk membayar. Murabahah sebagaimana digunakan dalam perbankan Islam, ditemukan terutama berdasarkan dua unsure : harga membeli dan biaya terkait dan kesepakatan berdasarkan mark-up (keuntungan). ${ }^{10}$

Adapun kelebihan kontrak murabahah (pembayaran yang ditunda) adalah sebagai berikut :

1. Pembeli mengetahui semua biaya yang semestinya sertta mengetahui harga pokok barang dan keuntungan (mark-up) yang diartikan sebagai prosentase harga keseluruhan dan ditambah biaya-biayanya.

2. Subyek penjualan adalah barang dan komoditas.

3. Subyek penjualan hendaknya memiliki penjual dan dimiliki olehnya dan ia seharusnya mampu mengirimkannya kepada pembeli.

4. Subyek penjualan memiliki penjual dan dimiliki olehnya dan ia hendaknya mampu mengirimkannya kepada pembeli.

5. Pembayaran yang ditunda. ${ }^{11}$

Murabahah sebagaimana diyakini disini, diterapkan pada setiap pembiayaan dimana ada komoditas yang dapat diidentifikasi untuk dijual. ${ }^{12}$

Bank-bank Islam pada umumnya menggunakan murabahah sebagai metode utama pembiayaan yang merupakan hampi $75 \%$ dari asetnya. ${ }^{13}$ Prosentase ini secara kasar bagi bankbank Islam dan juga sistem-sistem perbankan Islam di Pakistan dan Iran. Pada awal 1984 di Pakistan keuangan jenis murabahah berjumlah hamper 80 $\%$ dari seluruh keungan dalam investasi deposito bagi hasil. ${ }^{14}$ Sedangkan dalam kasus Bank Islam Dubai (DIB), Bank Islam sector swasta paling awal keuangan murabahah berjumlah $80 \%$ dari seluruh keuangan untuk tahun 1989. ${ }^{15}$ Bahkan untuk Bank Pembangunan Islam (IDB), lebih dari 10 tahun periode pembiayaan $73 \%$ seluruh keuangan berdasarkan murabahah pada pembiayaan keuangan perdagangan luar negerinya. ${ }^{16}$

$\begin{array}{lcr}\text { Beberapa } & \text { alasa } & \text { diberikan } \\ \text { popularitas } & \text { murababah } & \text { dalam } \\ \text { pelaksanaan investasi perbankan Islam; }\end{array}$

1. Murabahah adalah mekanisme penanaman modal jangka pendek dan dibandingkan dengan pembagian untung rugi atau bagi hasil .

2. Mark-up dalam murabahah dapat dibandingkan dengan bank-bank yang berbasis bunga dimana bank Islam sangat kompetitif.

3. Murabahah menghindari ketidakpastian yang dilekatkan pada perolehan usaha berdasarkan system bagi hasil ( PLS ). ${ }^{17}$ 
4. Murabahah tidak mengijinkan bank Islam untuk turut campur dalam manajemen

\section{Landasan Syari'ah}

1. Al-Quran :

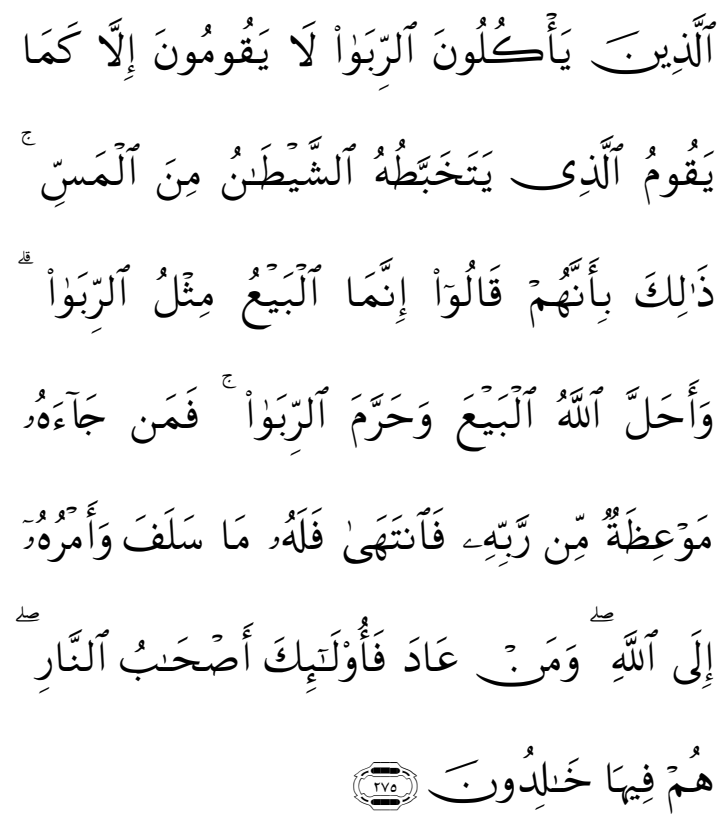

"Orang-orang yang makan (mengambil) riba[174] tidak dapat berdiri melainkan seperti berdirinya orang yang kemasukan syaitan lantaran (tekanan) penyakit gila[175]. keadaan mereka yang demikian itu, adalah disebabkan mereka Berkata (berpendapat), Sesungguhnya jual beli itu sama dengan riba, padahal Allah Telah menghalalkan jual beli dan mengharamkan riba. orang-orang yang Telah sampai kepadanya larangan dari Tuhannya, lalu terus berhenti (dari mengambil riba), Maka baginya apa yang Telah diambilnya dahulu[176] (sebelum datang larangan); dan urusannya (terserah) kepada Allah. orang yang kembali (mengambil riba), Maka orang itu adalah penghuni-penghuni neraka; mereka kekal di dalamnya”.

2. Al-Hadis :

Dari Suhaib ar-Rumi Radiyallahu Anhu, Rasulullah bersabda: Tiga hal yang didalamnya terdapat keberkahan: jual beli secara tangguh, muraqadah (mudharabah), dan mencampur gandum dengan tepung untuk keperluan rumah, bukan untuk dijual”. (HR. Ibnu Majah).

\section{Prinsip dan Mekanisme Murabahah dalam Perbankan Islam}

1. Syarat Jual beli Murabahah :

a. Penjual member tahu biaya modal kepada nasabah.

b. Kontrak pertama sah sesuai dengan rukun yang ditetapkan.

c. Kontrak harus bebas dari riba

d. Penjual harus menjelaskan kepada pembeli bila terjadi cacat atas barang sesudah pembelian.

e. Penjual harus menyampaikan semua hal yang berkaitan dengan pembelian, mislanya jika pembelian secara utang.

2. Tujuan Murabahah Kepada Pemesan Pembelian

Pertama, mencari pengalaman. Satu pihak yang berkontrak (pemesan pembelian) meminta pihak lain (pembeli) untuk membeli sebuah aset. Pemesan berjanji untuk ganti membeli aset tersebut dan memberinya keuntungan. Pemesan memilih sistem pembelian ini, yang biasanya dilakukan secara kredit, lebih karena ingin mencari 
informasi dibanding alasan kebutuhan yang mendesak teradap aset tersebut.

Kedua, mencari pembiayaan. Dalam operasi perbankan syariah, motif pemenuhan pengadaan aset atau modal kerja merupakan alas an yang mendorong dating ke bank. Pada gilirannya pembiayaan yang diberikan akan membantu memperlancar arus kas (Cash flow) yang bersangkutan.

\section{Beberapa Ketentuan Umum}

Tujuan dari perbandingan singkat ini adalah untuk melihat apakah ada perbedaan yang signifikan anatar pembiayaan yang berdasarkan murabahah dn bunga tetap untuk tujuan sama. Perbandingan menfokuskan pada aspek-aspek berikut : biaya resiko dalam pembiayaan murabahah, keamanan, hubungan antara bank dan pembeli, dan penyelesaian utang.

a. Biaya

Bank-bank Islam menyatakan bahwa kalau bank tradisional meminjamkan uang misalnya untuk membeli barang-barang tertentu, bunga yang diberikan pada pinjaman itu berkaitan dengan prinsip dan jatuh tempo pinjaman. Mereka menekankan juga bahwa pinjaman untuk tujuan tertentu bukanlah masalah dengan bank tradisional tentang biaya barang yang digunakan keperluan kliennya. Lebih dari itu, menurut bank-bank Islam perhatian utama dari bank tradisional adalah memperoleh suku bunga untuk kemajuan yang sama dalam pengertin resiko dan jatuh tempo. $^{18}$ Tanggung jawab dari klien setelah memperoleh pinjaman dengan suku bunga tertentu, untuk membeli barang yang ia perlukan berapa pun harganya. Argumen yang digunakan adalah metode murabahah bank Islam yang menjamin bahwa klien mengetahui terlebih dahulu seluruh biaya barang. Argumen ini tidak dikenal dalam pembiayaan yang berdasarkan bunga karena karena bunga yang dibayar pada saat bank membuat kesepakatan didepan, apakah pembayaran didepan itu mencakup seluruh biaya barang atau tidak. Selanjutnya suku bunga tetap atau variable pada kasus terakhir akan lebih sulit bagi klien untuk sampai pada keseluruhan biaya.

b. Murabahah : Bebas Resiko atau Bagi-Bagi Resiko

Keuntungan berdasarkan bagi-bagi resiko dimana model perbankan Islam secara teoritis diindetifikasi, 19 nampaknya bukan karakteristik dominan dari operasi murabahah dalam bak-bank Islam. Walaupun begitu dikemukakan oleh beberapa pendukung perbankan Islam bahwa yang terjadi dalam murabahah adalah bagi-bagi resiko, yang membenarkan pengembalian. Menurut Abdeen dan Shook, "bank mengambil 
resiko yang membenarkan keuntungan, sampai klien memenuhi janjinya semula untuk membeli komoditas. “20

Berikut pembahasan singkat resiko yang berkaitan dengan (i) barang, (ii) klien, (iii) pembayarannya.

Resiko yang terkait dengan barang. Bank Islam membeli barang yang diminta oleh klien murabahahnya, secara teoritis menimbulkan resiko kehilangan atau kerusakan barang dari waktu pembelian sampai waktu pengiriman kepada klien. Bank diwajibkan berdasar perjanjian murabahah untuk mengirimkan barang itu ke klien dalam kondisi baik. Menurut hukum Islam, klien berhak menolak barang yang rusak, menyimpang jumlahnya, atau tidk sesuai dengan spesifikasi.Dalam kasus murabahah yang berkaitan dengan perdagangan domestic, resikoresiko ini mungkin kurang berarti, tetapi dalam perdagangan internasional resiko-resiko semacam itu tidak boleh dihalalkan.

Resiko yang berkaitan klien. Janji klien untuk membeli barang yang diminta tidak mengikat dalam perjanjian murabahah, menurut mayoritas ahli hukum Islam. Karena klien memiliki hak untuk menolak membeli barang ketika bank Islam menawarkan kepada mereka untuk menjual. Dalam murabahah bank-bank Islam cenderung membenarkan

pengembalian pada operasi murabahah, paling penting berdasarkan resiko bisnis ini yang terkait dalam pelaksanaan. Nabi Shaleh mengatakan : Resiko bisnis diidentifikasi dengan fakta bahwa pembeli dalam transaksi murabahah tidak dipaksa untuk membeli komoditas yang telah ia pesan, tetapi selalu dapat berubah pikiran ketika waktu memiliki komoditas pesanan memenuhi semua permintaan dan standar yang ia minta. ${ }^{21}$

Resiko yang terkait dengan Pembayaran, Resiko tidak membayar penuh atau sebagian dari uang muka, sebagaimana yang direncanakan dalam kontrak, ada dalam pembiayaan murabahah. Bank Islam menghindari resiko ini dengan catatan janji, kemanan, jaminan pihak ketiga, dan istilah kontrak yang menyatakan bahwa semua keberlangsungan dari barang murabahah yang dijual kepada pihak ketiga (baik secara tunai maupun kredit) hendaknyaa didepositokan dengan bank sampai apa yang menjadi sebab bank dibayar secara penuh. ${ }^{22}$ Jika tidak adanya pembayaran karena faktorfaktor dimana klien tidak memiliki kontrol, maka bank Islam secara moral berdasarkaan kewajiban mesti merencanakan kembali hutang. Sebaliknya jika klien memiliki kemampuan untuk 
membayar tepat waktu, tetapi tidak maka bank dan RSBSnya mengambil konsep baik yang diterapkan pada klien. Jumlah baik tergantung kepada tingkat pengembalian normal pada dana bank yang diinvestasikan yang merupakan biaya kesempatan dari modal. ${ }^{23}$ Dalam beberapa kasus pemulihan uang muka tidaklah mungkin bank Islam bias merealisasikan keamanan untuk mengembalikan uang muka.

c. Keamanan

Menggunakan agunan dalam hutang, menurut Al-Quran dan AlHadis, tidak sendirinya tercela. AlQuran memerintahkan Muslim menulis kewajiban mereka dan jika perlu mengguakan agunan untuk hutang, sebagaimana dijelaskan dalam surah : AlBaqarah, ayat : 282 :

"Hai orang-orang yang beriman, apabila kamu bermuamalah tidak secara tunai untuk waktu yang itentukan, hendaklah kamu menuliskannya...."

Nabi dalam beberapa kesempatan memberikan kepada kreditor dengan agunan untuk hutang. Agunan adalah metode menjamin hak kreditor tidak dibayar dan menghindari makan hak orang lain tanpa ijin.Hal ini dijelaskan pula dalam surah Al-Baqarah, ayat : 188 :

"dan janganlah sebahagian kamu memakan harta sebagian yang lain diantara kamu dengn jalan yang bathil “.

d. Hubungan antara bank dank lien murabahah

Teori perbankan Islam menyatakan bahwa karakteristik dominan hubungan antara bank Islam dan kliennya adalah "partnership yang berdasarkan bagi hasil". Karakteristik ini dikemukakan dengan tujuan untuk mengeliminasi debitur-kriditur dalam hubungan klien bank tradisional. Namun sulit untuk menilai kerangka teoritis yang diberikan mengenai pentingnya pelaksanaan murabahah dalam perbankan Islam, yang berjumlah lebih dari 75 operasi investigasi bank-bank ini pada umumnya.

Menurut murabahah kontrak penjualan melibatkan hubungan anatar debitur-kreditur, antara klien dan bank masing-masing. Pembeli sepakat biaya barang ditambah mark-up dalam angsuran, jumlah dan waktu jatuh tempo yang dikhususkan pada waktu perjanjian. Setelah bank dan klien masuk dalam perjanjian ini, harga penjualan menjadi kewajiban hutang sisi klien kepada bank. Hubungan klien dengan bank ini menjadi hubungan debitur-kreditur. Ini yang menjadi dominan sama sekali tidak eksklusif, hubugan antara bank tradisi dan pelangganya.

e. Penyelesaian Hutang 
Pembiayaan venture berdasarkan murabahah dibayar tepat pada waktunya, tidak membedakan dari pembiayaan venture yang berdasarkan bunga tetap. Dalam kasus itu, hutang, dan biaya pembiayaan, apakah disebut bunga atau profit tetap dan waktu yang dimungkinkan untuk membayar juga tetap. Perbedaan yang paling signifikan adalah hal dimana debitur gagal membayar kembali hutang pada waktu tertentu. Pinjaman bunga pada umumnya menerima akhir bunga tambahan jika pinjaman tidak dibayar pada waktu tempo, apakah debitur mampu membayar atau tidak. Dalam kasus bank Islam, debitur hendaknya diberikan waktu untuk membayar jika ia tidak mampu membayar menurut perintah AlQuran, “ JIka debitur mengalami kesulitan, maka diberi kelonggaran sampai ia mengalami kemudahan. “._Hal ini dijelaskan dalam surah Al-Baqarah, ayat : 280

"Dan jika (orang berhutang itu dalam) dalam kesukaran, maka berilah tangguh sampai dia berkelapangan).

\section{PENUTUP}

Murabahah merupakan bentuk penjualan pembayaran yang ditunda dan perjanjian komersial murni, walaupun tidak berdasarkan pada teks Al-Quran atau As-sunnah, tetapi dibolehkan dalam hukum Islam. Bank-bank Islam telah menggunakan perjanjian murabahah dalam aktivitas pembiayaan melalui barang-barang dagangan dan memperluas jaringan penggunaanya.

Pembiayaan itu kini lebih $75 \%$ pembiayaan bank-bank Islam berdasarkan atas kepemilikan pengembalian yang telah ditetapkan sebelumnya pada investasi bank, seperti pengembalian bank-bank yang berdasarkan bunga yang ditetapkan sebelumnya.

Keuangan murabahah dan harga kredit yang lebih tinggi didalamnya jelas menunjukkan bahwa ada nilai waktu dalam pembiayaan yang berdasarkan murabahah, yang menuju walaupun tidak langsung kepada penerimaan nilai waktu uang.

\section{Catatan Akhir :}

${ }^{1}$ Lihat, Dr. Ibrhim Anis dkk, Al-Mu'jam Al-Wasith, juz I, hlm 322

${ }^{2}$ Lihat, Prof.Dr. Quraish Shihab, Wawasan Al-Quran, hlm 407

${ }_{3}^{3}$ Muhammad Ibn Ahmad Ibnu Muhammad Ibn Rusyd, ( Beirut : Bidayatul MUjtahid wa Nihayatul Muqtashid, Darul Qalam, 1988) vol.II hlm 216

4 Al Jaziri, Al-Fiqhi Ala Madzahibil Arba'a, juz II hlm 278-280

5 Muhammas Syafi'I Antonio, Bank Syariah dari Teori ke Praktik, Gema Insani Press, 2001, hlm 101

${ }^{6}$ Udovitch, Partnership and Profit, 221

${ }^{6}$ Al-Kaff, Does Islam Assign Any Value, hm 8

${ }^{7}$ Ibid, hlm 5-6

${ }^{8}$ Syafi'I, Al-Umm : juz III, hlm. 33

${ }^{9}$ Nawawi, Raudhatu at-Thalibin, hlm 526

${ }^{10}$ Mohammed, Islamic Bank Practices in Murabahah, hlm3-4

${ }^{11}$ Khan Aj, Devine Banking System, hlm. $39-40$

${ }^{12}$ At-Tamimi, Experience of Islamic Banks in The Middle East, hlm 33 
${ }^{13}$ Lihat, Dr. Ibrhim Anis dkk, Al-Mu'jam Al-Wasith, juz I, hlm 322

14 Lihat, Prof.Dr. Quraish Shihab, Wawasan Al-Quran, hlm 407

15 Muhammad Ibn Ahmad Ibnu Muhammad Ibn Rusyd, ( Beirut : Bidayatul MUjtahid wa Nihayatul Muqtashid, Darul Qalam, 1988) vol.II hlm 216

16 Al Jaziri, Al-Fiqhi Ala Madzahibil Arba'a, juz II hlm 278-280

17 Muhammas Syafi'I Antonio, Bank Syariah dari Teori ke Praktik, Gema Insani Press, 2001, hlm 101

${ }^{18}$ Udovitch, Partnership and Profit, 221 hm 8

19 Al-Kaff, Does Islam Assign Any Value,

${ }^{20}$ Ibid, hlm 5-6

${ }^{21}$ Syafi'I, Al-Umm : juz III, hlm. 33

${ }^{22}$ Nawawi, Raudhatu at-Thalibin, hlm 526

${ }^{23}$ Mohammed, Islamic Bank Practices in Murabahah, hlm3-4

\section{DAFTAR PUSTAKA}

Alrasid, Harun. Pengisian Jabatan Presiden. Cet. I. Jakarta: PT Pustaka Utama Grafiti, 1999.

Asshiddiqie, Jimly. Gagasan Kedaulatan Rakyat Dalam Konstitusi dan Pelaksanaan-nya di Indonesia. Jakarta: PT Ichtiar Baru Van Hoeve. 1994.

Berger, Raoul. Impeachment: The Constitutional Problems. Cambridge: Harvard University Press, 1974.

Black, Charles L. Impeachment: A Handbook. New Haven: Yale University Press, 1974.

Lijphart, Arend. Sistem Pemerintahan Parlementer dan Presidensial. Jakarta: PT RajaGrafindo Persada, 1995.
Mahendra, Yusril Ihza. Dinamika Tatanegara Indonesia: Kompilasi Aktual Masalah Konstitusi Dewan Perwakilan dan Sistem Kepartaian. Jakarta: Gema Insani Press, 1996.

Mahfud, Moh. Amandemen Konstitusi Menuju Reformasi Tata Negara. Yogyakarta: UII Press, 1999.

Mulyosudarmo, Suwoto. Peralihan Kekuasaan: Kajian Teoritis dan Yuridis terhadap Pidato Nawaksara. Jakarta: PT Gramedia Pustaka Utama, 1997.

Pandoyo, S.Toto. Ulasan Terhadap Beberapa Ketentuan UndangUndang Dasar 1945: Proklamasi dan Kekuasaan MPR. Yogyakarta: Liberty, 1992.

Soemantri, Sri. Tentang Lembagalembaga Negara Menurut UUD 1945. Bandung: PT Citra Aditya Bakti, 1993.

Whittington, Keith E. Constitutional Interpretation:Textual Meaning, Original Intent, and Judicial Review. Kansas: University Press of Kansas, 1999.

Yara, Muchyar. Pengisian Jabatan Presiden dan Wakil Presiden: Suatu Tinjauan Sejarah Hukum Tata Negara. Jakarta: PT Nadhilah Ceria Indonesia, 1995.

Zoelva, Hamdan. Impeachment Presiden: Alasan Tindak Pidana Pemberhentian Presiden Menurut UUD 1945. Jakarta: Konstitusi Press, 2005. 
Perubahan Pertama, Kedua, Ketiga, dan Keempat Undang-Undang Dasar Negara Republik Indonesia Tahun 1945.

UU No. 24 Tahun 2003 tentang Mahkamah Konstitusi. LN No. 98

Tahun 2003,TLN No. 4316. 